\title{
Proses pengambilan keputusan dalam keperawatan dan hubungannya dengan konsep berfikir kritis
}

\author{
Mutiara Unvi Zahra
}

Email : zahrazahrabatam845@mail.com

\section{LATAR BELAKANG}

Perawat merupakan disiplin ilmu dan profesi yang humanis dan ilmiah, yang tujuan utamanya adalah untuk melayani individu, kelompok, komunitas, masyarakat dan institusi. Perawat juga merupakan seorang praktisi yang berpendidikan dan diharapkan mempunyai kemampuan intelektual untuk menggunakan pemikiran rasional dan refektif saat perawat mempertimbangkan pengamatan dan informasi tentang kondisi masing-masing pasien. Sepanjang komponen dari proses keperawatan ,perawat menggunakan sikap dan kemampuan berfikir kritis untuk menentukan relevansi, makna dan iterrelasi data pasien serta untuk menetapkan asuhan keperawatan yang sesuai (Cristensen \& Kenney, 2009). Berpikir kritis juga dapat dikatakan sebagai konsep dasar yang terdiri dari konsep berpikir yang berhubungan dengan proses belajar dan kritis itu sendiri berbagai sudut pandang selain itu juga membahas tentang komponen berpikir kritis dalam keperawatan yang di dalamnya dipelajari karakteristik, proses, aplikasi berpikir kritis dan pengambilan keputusan yang etis dalam berpikir kritis. Kemampuan perawat mengidentifikasi masalah klien dan memilih solusi intervensi yang tepat tidak lepas dari kemampuan perawat berfikir kritis untuk menggali berbagai alasan berdasarkan evidence base dari setiap problem dan solusi yang teridentifikasi (Potter \& Perry, 2010).

Pengambilan keputusan dalam penyelesaian masalah adalah kemampuan mendasar bagi praktisi kesehatan, khususnya dalam asuhan keperawatan. Tidak hanya berpengaruh pada proses pengelolaan asuhan keperawatan saja, tetapi juga penting untuk meningkatkan kemampuan merencanakan perubahan. Perawat pada semua tingkatan posisi klinis harus memiliki kemampuan menyelesaikan masalah dan mengambil keputusan yang efektif, baik sebagai pelaksana/staf maupun sebagai pemimpin. 
Penyelesaian masalah dan pengambilan keputusan bukan merupakan bentuk sinonim. Pemecahan masalah dan proses pengambilan keputusan membutuhkan pemikiran kritis dan analisis yang dapat ditingkatkan dalam praktek. Pengambilan keputusan merupakan upaya pencapaian tujuan dengan menggunakan proses yang sistematis dalam memilih alternatif. Tidak semua pengambilan keputusan dimulai dengan situasi masalah. Jika dalam proses pengambilan keputusan dilakukan secara tergesa-gesa ataupun tidak tepat, ini akan berpengaruh bagi kualitas serta kuantitas pelayanan kesehatan kepada pasien. Berpikir kritis dapat dijadikan sebuah acuan bagi pelayanan yang akan diberikan pasien agar lebih cepat dan tepat dalam proses pengambilan keputusan. Maka dari itu berfikir kritis sangat diperlukan untuk bisa memberikan perawatan yang efektif.

\section{METODE}

Metode yang saya gunakan dalam membuat kajian ini adalah dengan menggunakan metode literature review. Dimana saya membaca beberapa referensi seperti jurnal ataupun buku-buku yang mendukung. Setelah membaca beberapa referensi, saya mengkaji dan membuat analisinya. Analisis dibuat sesuai thema judul yang saya ambil yaitu beekaitan dengan proses pengambilan keputusan oleh seorang perawat disertai dengan hubungannya dalam berfikir kritis.

\section{HASIL}

Dari hasil kajian saya didapatkan bahwa pengambilan keputusan sendiri adalah aspek penting dalam memberikan asuhan keperawatan. Pengambilan keputusan merupakan aspek yang menetukan apakah asuhan keperawatan yang diberikan sudah sangat efektif atau tidak. Selain itu pada proses pengambilan keputusan ini sendiri sangat dibutuhkan yang namanya berfikir kritis atau critical thinking. Seperti yang disebutkan dijurnal sumber yang saya baca bahwa Berpikir kritis (critical thinking) merupakan kompetensi utama yang menunjang praktik klinik keperawatan (Simpson \& Courtney 2002). Berpikir kritis merupakan pondasi bagi perawat untuk melakukan penalaran, mengidenti-fikasi dan mengatasi masalah pasien dan mengambil keputusan klinik. Sebagai luarannya, berpikir kritis secara signifikan berpengaruh terhadap perilaku caring (Mulyaningsih, 2011).

Dari pengertian pengertian tersebut saja sudah sangat jelas bahwa pada setiap proses pengambilan keputusan yang berhubungan dengan proses keperawatan sangat 
dibutuhkan yang namanya berfikir kritis. Berfikir kritis akan membantu perawat dalam memecahkan masalah dan mengambil keputusan dengan baik. Dalam praktek sehari-hari perawat harus membuat keputusan diagnostik yang terkait dengan tugasnya dalam melakukan asuhan keperawatan. Selain memberi asuhan keperawatan juga sering kali dituntut untuk dapat membantu dalam pemecahan masalah yang dihadapi oleh klien. Oleh karena itu perawat memerlukan pemikiran kritis, ketrampilan interpersonal dan berlandaskan etika keperawatan sehingga pasien dapat terbantu dalam mengambil keputusan.

\section{PEMBAHASAN}

Proses pengambilan keputusan adalah salah satu penyelesaian yang dinamis. Penyebab umum gagalnya pengambilan keputusan adalah kurang tepat dalam mengidentifikasi masalah. Oleh karena itu, identifikasi masalah merupakan langkah yang paling penting karena kualitas hasil tergantung pada keakuratan hasil dalam mengidentifikasi masalah.

Pengambilan keputusan adalah suatu pendekatan yang sistematis terhadap hakekat suatu masalah dengan pengumpulan fakta-fakta dan data, menentukan alternatif yang matang untuk mengambil suatu tindakan yang tepat.

Lima hal yang perlu diperhatikan dalam pengambilan keputusan :

1. Dalam proses pengambilan keputusan tidak terjadi secara kebetulan.

2. Pengambilan keputusan tidak dilakukan secara sembrono tapi harus berdasarkan pada sistematika tertentu :

Tersedianya sumber-sumber untuk melaksanakan keputusan yang akan diambil. Kualifikasi tenaga kerja yang tersedia

Falsafah yang dianut organisasi.

Situasi lingkungan internal dan eksternal yang akan mempengaruhi administrasi dan manajemen di dalam organisasi.

3. Masalah harus diketahui dengan jelas.

4. Pemecahan masalah harus didasarkan pada fakta-fakta yang terkumpul dengan sistematis. 
5. Keputusan yang baik adalah keputusan yang telah dipilih dari berbagai alternatif yang telah dianalisa secara matang.

Apabila ke lima hal hal diatas tersebut tidak diperhatikan pada saat pengambilan keputusan, maka akan terdapatlah beberapa masalah yang akan terjadi diantaranya ialah :

Tidak tepatnya keputusan.

Tidak terlaksananya keputusan karena tidak sesuai dengan kemampuan organisasi baik dari segi manusia, uang maupun material.

\section{Ketidakmampuan pelaksana} untuk bekerja karena tidak ada sinkronisasi antara kepentingan organisasi dengan orang-orang di dalam organisasi tersebut.

Timbulnya penolakan terhadap keputusan

Definisi Berpikir kritis adalah proses kognitif atau mental yang mencakup penilaian dan analisa rasional terhadap semua informasi dan ide yang ada serta merumuskan kesimpulan dan keputusan (Suddarth dan
Brunner, 1998). Sedangkan menurut Yahiro dan Saylor dalam Perry dan Potter (2005), menyatakan bahwa berpikir kritis adalah reflektif, pemikiran yang masuk akal tentang masalah keperawatan tanpa ada solusi dan difokuskan pada keputusan yang harus diyakini dan dilakukan. Menurut Strader dalam Perry dan Potter (2005), menyatakan berpikir secara kritis menantang individu untuk menelaah asumsi tentang informasi terbaru dan untuk menginterpretasikan serta mengevaluasi uraian dengan tujuan mencapai simpulan suatu perspektif baru.

Berpikir kritis adalah sebuah komitmen untuk berpikir jernih, tepat dan akurat, serta bertidak sesuai dengan keadaan. Berpikir kritis tidak hanya memerlukan kemampun kognitif, tetapi juga kebiasaan seseorang untuk bertanya, mempunyai hubungan yang baik, jujur, dan selalu mau untuk berpikir jernih tentang suatu masalah. Perawat yang menerapkan pemikiran kritis dalam bekerja akan fokus terhadap penyelesaian masalah dan membuat keputusan, serta tidak akan membuat keputusan yang terburu-buru ataupun ceroboh.

Perawat yang bekerja dalam situasi kritis seperti di unit gawat darurat sering bertindak terlalu cepat pada saat ada masalah. Namun, perawat tersebut telah berlatih disiplin dalam membuat suatu keputusan untuk menghindari 
keputusan yang terlalu cepat dan tidak tepat. Belajar berpikir kritis akan membantu untuk merawat klien dimana seorang perawat akan menjadi seorang pemberi saran, dukungan, dan akhirnya dapat membantu klien untuk menentukan pilihan terkait dengan perawatan (Facione dan Facione, 1996) menentukan konsep untuk berpikir kritis.

Ilmu keperawatan berkembang sangat cepat dan akan selalu ada informasi baru yang dapat diterapkan dalam praktik. Berpikir kritis merupakan tanda atau standar untuk perawat professional yang kompeten. Kemampuan untuk berpikir kritis, meningkatkan praktik klinik dan mengurangi kesalahan pada penilaian klinis adalah visi dari praktek keperawatan (Di vito-Thomas, 2005).

Menurut Gaberson \& Oermann, (2010) pemikiran kritis memungkinkan perawat membuat penilaian yang beralasan dan terinformasi dalam setting praktik dan memutuskan apa yang harus dilakukan dalam situasi tertentu. Begitupun dengan kepercayaan diri merupakan komponen utama pengambilan keputusan yang benar dalam konteks klinis dan untuk proses penilaian terkait. Berbagai penelitian menunjukkan bahwa kepercayaan diri untuk bereaksi terhadap situasi darurat meningkat saat faktor seperti latihan berulang dan latihan simulasi hadir (Carlos et al.,2014).

Adapun beberapa karakteristik berpikir kritis yaitu :

\section{Konseptualisasi}

Artinya proses intelektual membentuk suatu konsep.

\section{Rasional dan Beralasan}

Artinya argument yang diberikan selalu berdasarkan analisis dan mempunyai dasar kuat dari fakta fenomena nyata.

\section{Reflektif}

Artinya bahwa seorang pemikir kritis tidak menggunakan asumsi atau persepsi dalam berpikir atau mengambil keputusan tetap akan menyediakan waktu untuk mengumpulkan data dan menganalisisnya berdasarkan disiplin ilmu, fakta dan kejadian.

\section{Berpikir adil dan Terbuka}

Yaitu mencoba untuk brubah dari pemikiran yang salah dan kurang menguntungkan menjadi benar dan lebih baik.

Pemikir yang kritis akan memperhatikan apa yang penting dalam sebuah situasi, membayangkan dan mengeksplorasi semua alternatife, mempertimbangkan kode etik, 
dan kemudian membuat suatu keputusan. Cara untuk meningkatkan kemampuan berpikir kritis diantaranya ialah pertama, membaca dengan kritis. Untuk berpikir secara kritis, seorang perawat harus bisa membaca dengan kritis pula dalam hal itu penting juga kita mengetahui bagaimana aplikasi berpikir kritis dalam keperawatan yaitu :

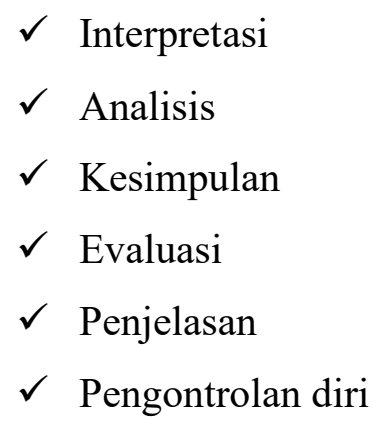

Dalam berpikir kritis salah satu komponen peting dalam pengambilan keputusan yang digunakan untuk mempertimbangkan pemecahan masalah yang akan diambil. Berpikir kritis merupakan proses kognitif level tinggi, karena termasuk dalam pengembangan kreativitas, pemecahan masalah dan pengambilan keputusan. Pengambilan keputusan dalam keperawatan diaplikasikan dengan cara membangun model dari beberapa disiplin ilmu yang antara lain adalah ekonomi, philosophy, politik, psikologi, teori operasional, administrasi bisnis, administrasi kesehatan, kebijakan kesehatan dan ilmu keperawatan. Model dibuat lebih spesifik dalam pemecahan masalah etika dan permasalahan klinis. Untuk dapat melaksanakan pengambilan keputusan dengan baik, maka perlu adanya analisa kritis yang antara lain adalah menyusun pertanyaan-pertanyaan terkait.

Kemampuan berpikir kritis dapat ditingkatkan dengan motivasi yang positif dari lingkungan tempat perawat bekerja. Suatu kreativitas penting untuk membangkitkan motivasi secara individu, sehinnga seorang peraeat mampu mengembangkan konsep baru dengan pendekatan inovatif dalam memecahkan masalah agar keputusan yang diambil akurat dan jelas. Perawat juga harus terbuka dalam menerima kritik karena akan mengakibatkan hal yang positif.

\section{PENUTUP}

Dalam suatu proses pengambilan keputusan yang dilakukan oleh seorang perawat maupun mahasiwa keperawatan haruslah didasari dengan pemikiran yang kritis serta seuai structural tahap tahap pengambilan keputusan yang ada. Berfikir kritis ialah salah satu aspek yang sangat penting dan tidak boleh diabaikan dalam pengambilan keputusan yang akan dilakukan. Berfikir kritis akan membantu dan mempengaruhi asuhan keperawatan yang akan diberikan. 
Dalam pengambilan keputusan itu sendiri tidak boleh dilakukan dengan semberono dan juga tergesa gesa. Seorang perawat harus selalu memperhatiakn setiap aspek dan juga melakukan yang terbaik sebelum tindakan dilakukan. Maka dari itu mengasah kemampuan berfikir kritis sangatlah diperlukan sejak dini.

\section{DAFTAR PUSTAKA}

Arli. K.S, (2017). Critical Thinking and Caring in Nursing Students. International Journal of Caring Sciences, vol. 10(1), 471-478

* Budiono \& Budi. (2015). Konsep dasar keperawatan. Jakarta : Bumi medika.

* Cynthia Lee Terry, Aurara Weaver. (2013). Keperawatan kritis. Yogyakarta : Rapha Publishing

* Daniati,dkk. (2018). pengaruh Berpikir Kritis Terhadap kemampuan Perawat Pelaksana dalam melakukan asuhan keperawatan di Rumah Sakit Hermina Bekasi, Jurnal kesehatan holistik, vol 12, No.1

* DS, Bambang Sudono., A, Dhani Setya., \& H, Rif Atiningtyas. (2017). Gambaran Kemampuan Berpikir Kritis Perawat Primer dalam Pelaksanaan Asuhan Keperawatan di Rumah Sakit Islam Surakarta. Jurnal Ilmu Keperawatan Indonesia, vol. 10(1), 79-106.
Fathi, A, A \& Simamora, R.H. (2019, March). Investigating nurses' coping strategies in their workplace as an indicator of quality of nurses life in Indonesia : a preliminary study. In IOP Conference Series : Earth and Environmental Science, Vol. 248, No.1, p.012031). IOP

Publishing

* Indriate. (2013). Berfikir Kriris dalam Proses Keperawatan. Jurnal Keperawatan, vol. 6(2), 89-93

* Kowiyah. (2012). Kemampuan Berpikir Kritis. Jurnal Pendidikan Dasar, vol. 3(5), 175-179.

Mulyaningsih. (2013). Peningkatan perilaku caring melalui kemampuan berpikir kritis perawat. Jurnal Manajemen Keperawatan, vol. I(2), 100-106

- Patmawati, dkk (2018). Efektifitas Metode Pembelajaran Klinik Terhadap Kemampuan Berpikir Kritis dan Kepercayaan Diri Mahasiswa Keperawatan. Jurnal Keperawatan Muhammadiyah, vol. 3(2), 89-92

* Simamora, R. H. (2019). Menjadi perawat yang: CIH'HUY. Surakarta: Kekata Publisher.

* Simamora, R. H. (2005). Hubungan Persepsi Perawat Pelaksana Terhadap Penerapan Fungsi Pengorganisasian Yang Dilakukan Oleh Kepala Ruangan Dengan Kinerjanya Diruang Rawat Inap 
RSUD Koja Jakarta Utara (Doctoral dissertation, Tesis FIK UI, Tidak dipublikasikan).

* Surtiyanti, Y., \& Mulyadi. (2019).

Analisis Faktor-Faktor yang Mempengaruhi Penerapan Berpikir Kritis Perawat dalam Melaksanakan Asuhan Keperawatan di Rumah Sakit. Jurnal Keperawatan Raflesia, vol. 1(1), 21-32.

* Suwarma, Dina Mayadiana. (2019).

Kemampuan Berpikir Kritis. Jakarta:

Cakrawala Mahakarya. 